\title{
MODELLING DIFFERENT POSSIBILITIES TO USE A FREQUENCY INVERTER DRIVE
}

\author{
Márton Károly FÜLÖP \\ University of Debrecen, Debrecen, Hungary, fulop.marton96@gmail.com
}

\begin{abstract}
In many fields of industry frequency inverter drive is used to generate rotation when, due to a given technology or production process, modifying the speed of the engine is necessary. In this article we introduce a model built by us, through which we present the frequency inverter drive's principles of utilization from different fields of industry and by using industrial automation de-vices. Through this model one can be familiarized with the 4 methods created by us that can be controlled through a complex yet easy to understand and user-friendly HMI
\end{abstract}

Keywords: frequency inverter, asynchronous motor, PLC, HMI, conveyor.

\section{Introduction}

In the industry, the most common electric rotary machine is the 3 phase asynchronous motor. These electric motors are used in many technological processes from conveyors and pumps to ventilators. In many cases these motors have to work on a different rotation speed than that which occurs under the usual network voltage between $50-60 \mathrm{~Hz}$. In these cases the asynchronous motor's speed has to be changed. [1], [2].

$$
\begin{aligned}
& s=\frac{n_{0}-n}{n_{0}} \Rightarrow n=(1-s) \cdot n_{0} \\
& n_{0}=\frac{f_{1}}{p} \\
& n=\frac{f_{1}}{p} \cdot(1-s)
\end{aligned}
$$

s - slip [-];

$\mathrm{n}_{0}$ - speed of magnetic field in the stator [1/min];

$\mathrm{n}$ - speed of the rotor $[1 / \mathrm{min}]$;

$\mathrm{f}_{1}$ - frequency [Hz], [1/sec];

$\mathrm{p}$ - number of pole pairs [-].

From the third equation it can be seen that speed is influenced by three factors: frequency, the number of poles and the slip. If any of these three change, the speed of the engine also changes.

\section{Principles of use}

During the research we identified five different principles of general use in the applications of the frequency inverter drive:

- use of more, pre-adjusted speed;

-modification of linear speed between two values;

- optimization of acceleration time;

- optimization of braking time;

- keeping the speed constant under modified load.

By using these principles frequency inverter drives are applied in many different fields, from building automation, through transporting of materials to university research. [3]

\section{Devices used and their communication}

In order to create this model we used industrial automation devices from Mitsubishi Electric, a frequency inverter (Mitsubishi DR-E720S-008SC-EC), a PLC (Mitsubishi FX3GE-24MT/DDS), an HMI (Mitsubishi GT1045-QSBD), and its software (GX Works2, GT Designer3), the sensors of Bernstein (Bernstein KCN-T12PS/004-KLP2) those which are distributed by Festo too, a three phased asynchronous motor (0,18 [kW]; 230 [V]; 1,15 [A]; IP55) produced by Carpanelli (Carpanelli M63B4) and a conveyor belt that we found at the department. 


\subsection{Communication between the devices}

Figure 2. illustrates the communication between devices in our system. Between the HMI and PLC, communication is achieved by means of a RS422 connection. The inputs and outputs of the PLC send and receive data through the frequency inverter's terminals. The 3 phases of the motor are connected to the frequency inverter according to the method described in the frequency inverter's manual, therefore the frequency inverter can control the motor properly according to the controller and regulatory signals that it receives. For security reasons we built in an emergency switch between the motor and the frequency inverter allowing us to disconnect the motor at any time without turning off the frequency inverter.

\subsection{Establishing the parameters of the fre- quency inverter}

In order to ensure the smooth communication between the frequency inverter, the motor and the PLC, the frequency inverter has to have certain parameters. The maximal and minimal frequency, the acceleration and braking times, the dataset of the motor and the settings for the terminal connections are all necessary for the system's safe operation. We set these parameters manually.

The analog output terminals communicate through 0-10 [V] signal level but on the analog input the signal level has to be chosen, therefore we set $0-10[\mathrm{~V}]$ communication signal level to the input terminals too. Basically the analog input terminal 4 is inactive on the frequency inverter.

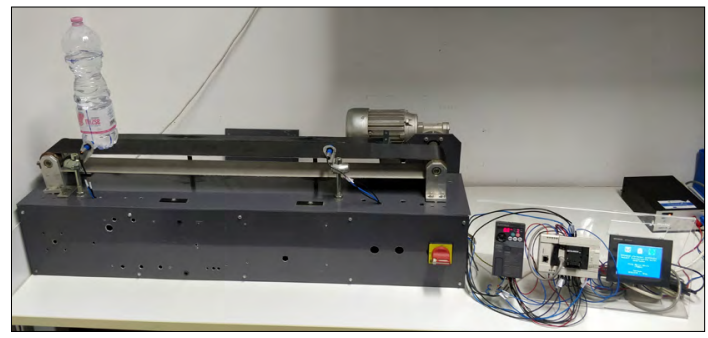

Figure 1. The built model

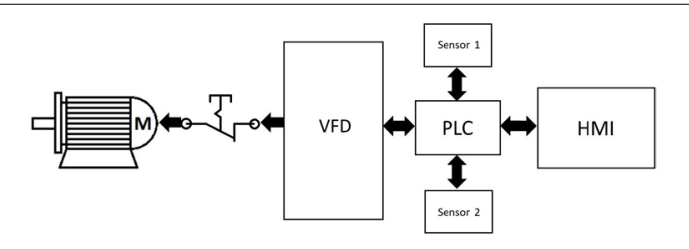

Figure 2. The schematic figure of the communica-tion between devices
Because the frequency inverter used by us is the smallest member of the product family, both in terms of size and performance, we had to reset the parameters as AU signal terminal and activate it in order to make terminal 4 usable.

\section{Presentation of the finished model}

We wrote the controller PLC programs in GX Works2 developed by Mitsubishi Electric, while the HMI interface's visualization was made in the GT Designer3 application framework.

After launching the system we get a general description of the model, then on the third page we can choose the example we want to apply. When the system was designed it was important to make it easy to use, so we divided the four programs into two groups (one for the first and the second program, another for the third and the fourth program) and within these groups the interfaces are slightly different from each other. The system includes more safety functions, for example only one program can be active at any given time. [4]

In the PLC program a mixed programming language (Ladder/FBD) was chosen to write the program, because in this programming framework signal processing is easy. The digital control and the conditions were created in a ladder diagram while the analog control and feedback were written in a block diagram. [5], [6], [7]

\subsection{The first program group}

The interfaces of the first two programs are made up by 3 pages each.

On the first page of the HMI interface the information needed to the control of the program are displayed. On the second page the motor's direction of rotation can be chosen, there are also the start, stop and pause functions. The third page can be accessed only after the conveyor has been started, there the conveyor's speed can be set by modifying the frequency; there is a real time picture of the frequency change both as a diagram and in numerical value.

In the first example the motor's speed can be modified between three preset frequencies; doing that also changes the conveyor's speed. This kind of application is suitable for changing the speed of mixing tanks' rotary tools in the food industry. For example, when different types of materials have to be mixed (and due to their different viscosity or technological process) some of them have to be mixed on lower speed, while others require higher speed. This solution is also applied 


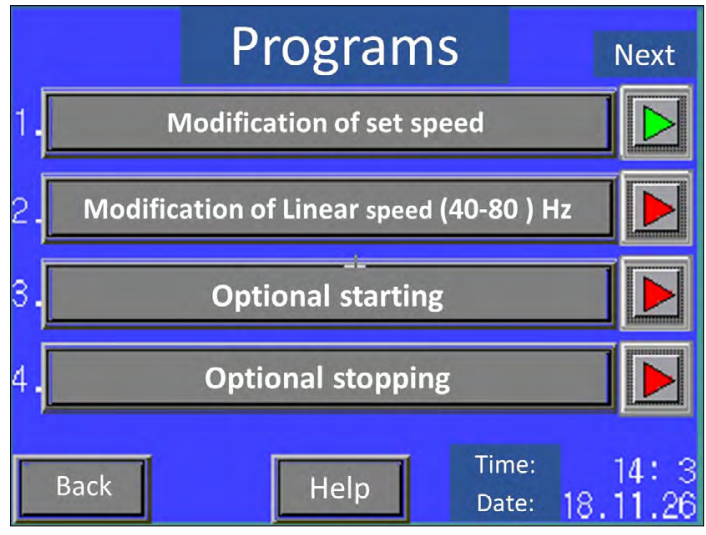

Figure 3. The third page of the system (the selec-tion of the program)

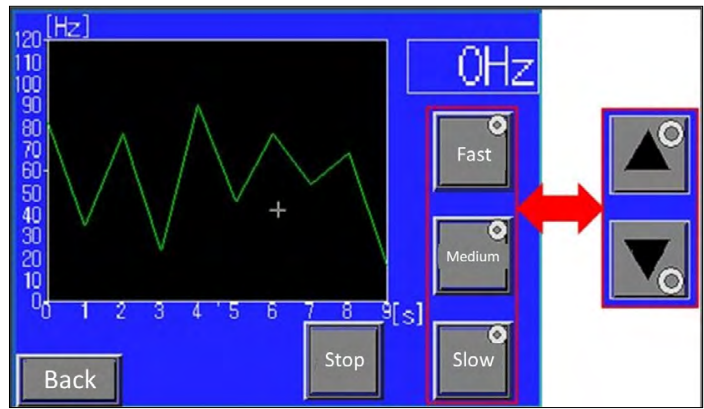

Figure 4. The difference between the three interfaces of the first two programs

in mechanical machining devices or building automation.

In the second example the frequency can be modified on a pre-determined scale by increments of one hertz. This is used for industrial ventilators, delivery trucks or the processes mentioned above, when speeds that are different from the preset values are required

\subsection{The second program group}

The interfaces of the third and fourth programs are also made up of 2 pages each.

On the first page there is information that is necessary to control the programs. On the second page the conveyor can be started or stopped, slow starting/stopping can also be activated and deactivated. In both programs we have the password protected possibility to change the starting/stopping speed.

In the third program we present the conveyor's optional staring. This program can be used in the case of controlled, progressive launch of conveyors or delivery trucks, in order to prevent the capsizing of materials as an effect of sudden starting.

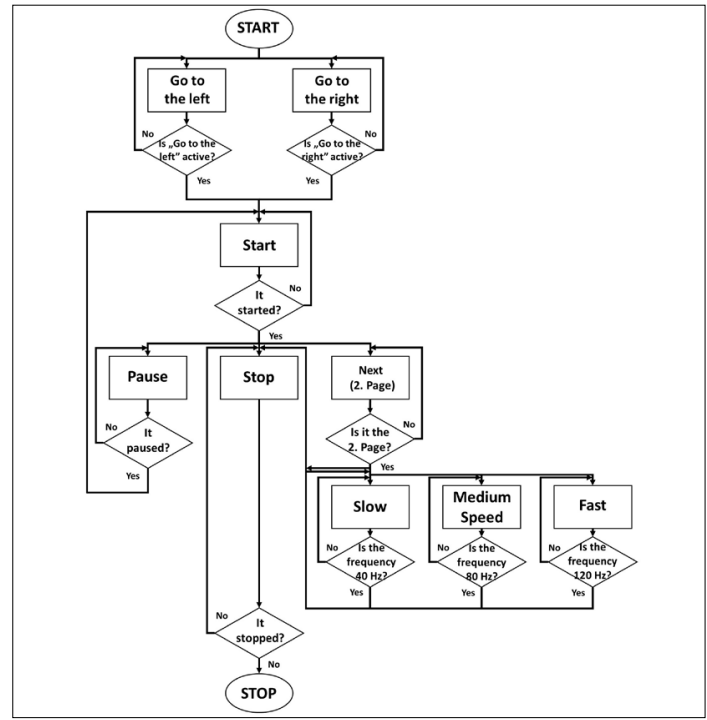

Figure 5. Flow diagram of "Modification of set speed"

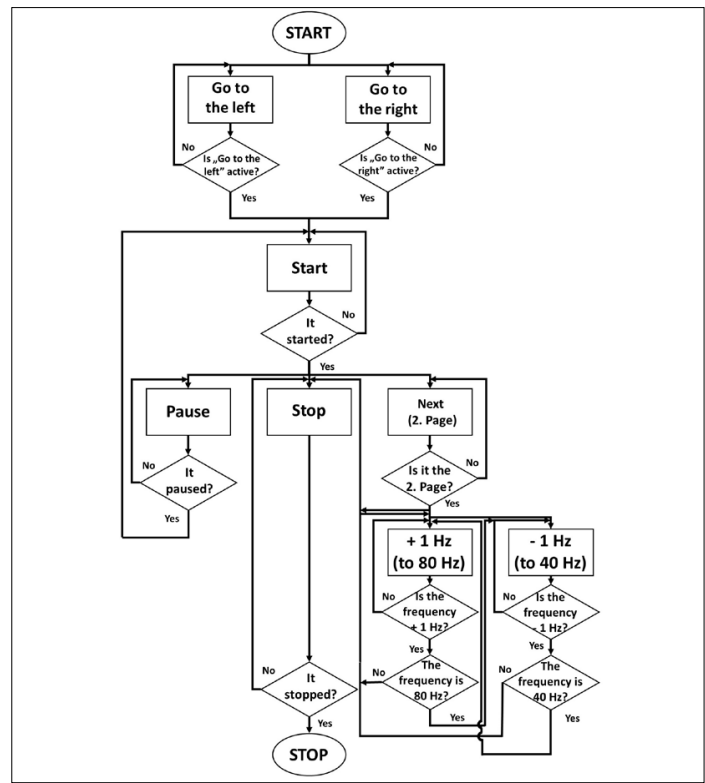

Figure 6.Flow diagram of „Modification of Linear speed $(40-80 \mathrm{~Hz})$

In the fourth program we show the conveyor's optional stopping. This program, similar to the previous example, can be used in the case of controlled stopping of conveyors or delivery trucks, in order to prevent the capsizing of materials as an effect of sudden stopping. In the case of elevators (e.g.: lift) positioning can be made, so the moved product won't run past the required end position. 


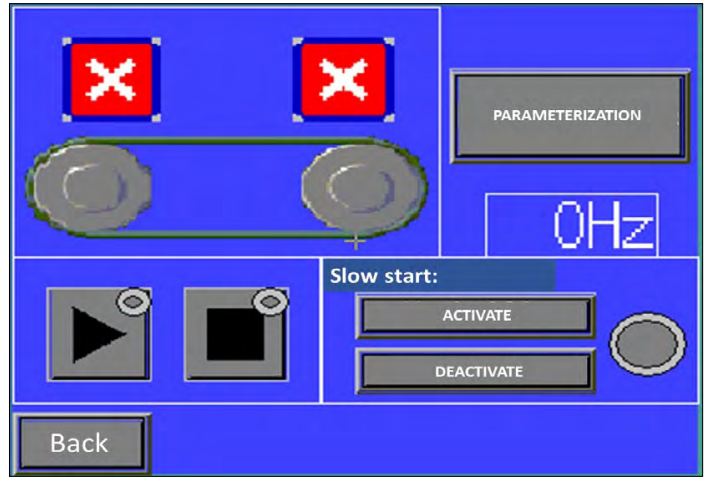

Figure 7. Second interface of „Optional starting”

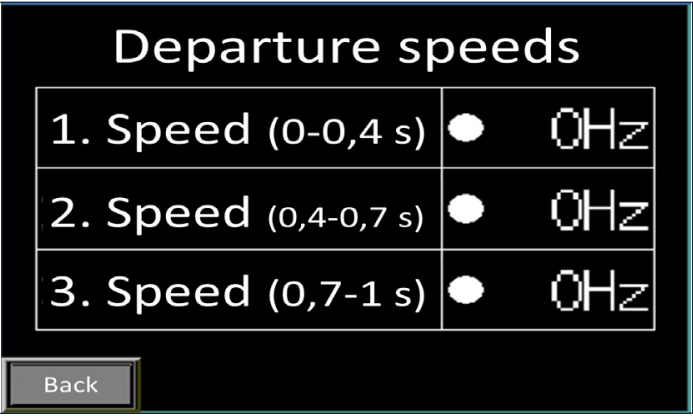

Figure 8. Third interface of „Optional starting”

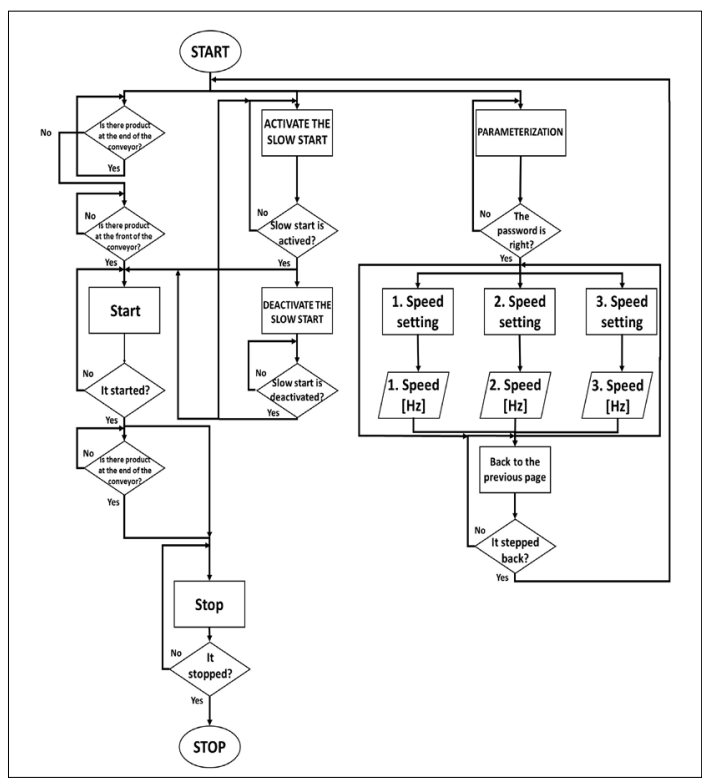

Figure 9. Flow diagram of „Optional starting”

\subsection{The fifth program group}

TAmong future plans we'd like to create a fifth program by which the conveyor will be able to keep its speed constant under changing load. This example is used in the timber industry in the case of saw disk drives where the hardness of the processed wood changes. Furthermore it is applied in case of pumps and hydraulic power supplies to keep pressure constant. The creation of this program was not necessary, because in the frequency inverter chosen by us this function already exists and works.

\section{Conclusions}

By means of industrial devices we created a complex mechatronical system by which the utilization principles of frequency inverter drives under industrial circumstances can be demonstrated. On the operator interface we can get a real time picture of the frequency change. For safe functioning in many cases the modification of the given parameters is password protected.

This system can be used with great results for educational purposes at universities, practical lessons and training programs by companies. Through our model four different solutions can be presented at once for the application of the frequency inverter so it is suitable for demonstrations of certain industrial processes and their solutions.

\section{The working of my model:}

\section{https://youtu.be/oG2GZd39ds4}

\section{References}

[1] Kuczogi E.: Villamos hajtások. Műszaki könyvkiadó, Budapest, 1976.

[2] Tóth J.: Automatika. TERC Kereskedelmi és Szolgáltató Kft, Budapest, 2013.

[3] Bartha I., Husi G., Liker I., Vitéz A., Tóth J.: Kapcsolási elrendezés és eljárás elektromos jármü váltakozó áramú hajtásának vezérlésére. P1200240. Magyarország, 2013.

[4] Sipos K., Tóth J.: Elektropneumatikus szelepek áramlási veszteségének mérése ipari eszközökkel. Műszaki és Menedzsment Tudományi Közlemények 2. kiadás, 2017. 68-72.

[5] Dombi K. B., Tóth J.: Meglévő automatizált épületek integrációja. In: A XXIII. Fiatal müszakiak tudományos ülésszak előadásai. Proceedings of the $23^{\text {rd }}$ international scientific conference of youngth engineers, Kolozsvár/Cluj, Románia, Műszaki Tudományos Közlemények 7. (2018) 67-70.

[6] L. Coutinho Alves Meiga, Tóth J.: Control and Position Memory of a TTR Robot. Annals of the University of Oradea Fascicle of Management and Technological Engineering 25. (2016) 115-118.

[7] Tóth X. E., Tóth J.: How to Control a Pneumatical and an Electrical Driven Linear. Annals of the University of Oradea Fascicle of Management and Technological Engineering. 24. (2015) 185-188. 